ECONOMICS

THE GENDER WAGE GAP IN PAID- AND SELF-EMPLOYMENT IN AUSTRALIA

by

Kristy Eastough

The University of Western Australia

\author{
and
}

Paul W. Miller

The University of Western Australia 


\title{
THE GENDER WAGE GAP IN PAID- AND \\ SELF-EMPLOYMENT IN AUSTRALIA*
}

by

\author{
Kristy Eastough \\ Business School \\ The University of Western Australia
}

and

Paul W. Miller

Business School

The University of Western Australia

* Miller acknowledges financial assistance from the Australian Research Council. Helpful comments were received from two anonymous referees. We are grateful to Barry Chiswick for discussions that prompted the research for this paper. 
THE GENDER WAGE GAP IN PAID- AND

SELF-EMPLOYMENT IN AUSTRALIA

\begin{abstract}
This paper presents an analysis of the gender wage gap in the highly regulated Australian labour market. It compares wage outcomes in the wage and salary sector with those for the self-employed. Comparisons with the United States are provided. The large gender pay gap in self-employment suggests that the aggregate gender wage differential will not be eliminated solely through wage determination for wage and salary earners. The greater gender wage gap in the self-employed sector may reflect liquidity constraints that are more difficult for self-employed women to overcome relative to self-employed men. The comparisons with the United States suggest that women will experience deterioration in relative earnings as the Australian labour market is deregulated.
\end{abstract}




\section{THE GENDER WAGE GAP IN PAID- AND SELF-EMPLOYMENT IN AUSTRALIA}

\section{INTRODUCTION}

Australian women experience an earnings disadvantage compared to Australian men.

However, this earnings disadvantage, which is estimated in econometric studies to be around 12-14 percent, is one of the lowest in OECD countries. ${ }^{1}$ The relatively small female earnings disadvantage in Australia is generally attributed to the comparatively high degree of labour market regulation. Of particular note is the system of centralised wage determination that was instrumental in the implementation of two major equal pay decisions in the early 1970 s.

Most of the studies of the gender earnings differential in Australia have been conducted for the aggregate labour market. In contrast, the study of earnings on the basis of birthplace has included a disaggregated analysis to examine the earnings disadvantage of immigrants in various segments of the labour market. Kidd (1993a), for example, disaggregated the overseas born on the basis of whether their country of origin was English speaking. He also examined the birthplace earnings differentials by sector of employment. In particular, differences in earnings determination between the self-employed and workers in paid employment were examined. This disaggregated analysis by sector of employment was shown to develop understanding of the labour market experiences of immigrants in Australia.

This study attempts to provide further information on the gender wage gap in Australia through separate study of the self-employed and wage and salary earners. Comparable analyses are conducted for the US labour market using data from the same time period and specifications of estimating equations that are as close as possible to those used for Australia. These international analyses are used to comment on the extent to which the findings for the Australian labour market are attributable to the higher degree of labour market regulation in this country.

\footnotetext{
${ }^{1}$ As outlined in Section III, these econometric studies decompose the overall difference between average male and average female earnings in the working population into a component that can be explained by differences between males and females in the mean values of the regressors included in the model of earnings, and a component that cannot be explained in this way. This latter, unexplained, component is what is termed a gender wage/earnings gap or wage/earnings disadvantage in this study. The overall difference in mean earnings is termed the gender wage/earnings differential.
} 
The structure of this paper is as follows. Section II provides a brief history and background of the gender wage differential in Australia. Section III establishes a theoretical framework for the study of wage determination and discrimination. Empirical analyses using the 1991 Australian Census and the 1990 United States Census are presented in Sections IV and V respectively. Section VI contains policy implications and a conclusion.

\section{LITERATURE REVIEW}

The Australian labour market of the $20^{\text {th }}$ century was characterised by centralised and regulated wage determination whereby the Australian Industrial Relations Commission (AIRC) and its predecessors determined wage rates through awards and made rulings to settle industrial disputes. The determination of female wages was first explicitly addressed in the Rural Workers Case of 1912. This case established two principles which formed the basis for female wage determination over the next half century. First, when women were performing the same work as men they were to be paid the same rate to prevent males being displaced by cheaper female labour. Second, where women were of little threat to male employment, because they were in female dominated occupations, they were to be paid fifty four to sixty six percent of the male rate (Short 1986, p.316). These two basic principles dominated female wage determination until the equal pay case of 1969 (Short 1986, p.317).

Equal Pay for Equal Work was introduced in 1969. While this decision was aimed at rectifying the explicit institutional discrimination that had been part of wage determination in Australia since the beginning of the $20^{\text {th }}$ century, it did not achieve equal pay. This was because the highly segregated nature of the Australian labour market meant that equal pay only applied to women doing the same type of work as men, which accounted for a mere 18 percent of all working women (Short 1986, p.319). The failure to achieve pay equity was the impetus behind the Equal Pay for Work of Equal Value decision of 1972. This ruling was designed to recognise the consistent under-valuation of work performed by females. From 1969 to 1977 average minimum award wages for female employees rose from 72 to 92 percent of the average minimum award wages for male employees. 
Legislative reform aimed at closing the gender wage gap continued in the 1980s. The Sex Discrimination Act of 1984 prohibited discrimination based on sex, marital status, pregnancy and family responsibilities (Kidd and Meng 1997, p.32). The Affirmative Action Act of 1986 established proactive strategies aimed at compensating for the effects of past discrimination (Whitehouse 1992, p.66).

A shift to enterprise bargaining began in 1987, when, as part of the national wage case the AIRC introduced a two-tiered system of wage determination. Under this system, while base level wage increases were determined by the national wage case, second tier wage increases were determined at the enterprise level and were to be linked to improvements in productivity. Since this decision, there has been a gradual decline in the award system and powers of the AIRC and a shift towards enterprise bargaining arrangements (see Wooden (2000) for an overview).

Since the early 1980s, economists have studied the gender wage differential intensively, attempting to explain why, after the equal pay decisions, women continued to earn less than men. In general these studies have applied Mincer's (1974) human capital model and the Blinder (1973) decomposition to measure the female wage disadvantage. $^{2}$ Borland (1999) presents an overview of the main studies. This shows that the studies have varied considerably in terms of their coverage (all employees versus wage and salary earnings, all workers versus workers in specific age groups, full-time versus full- and part-time workers), definition of the dependent variable (hourly or weekly earnings) and specification of the estimating equations. There is, consequently, quite an array of results, but most research conducted since 1980 shows that between 60 and 90 percent of the difference between average male and average female wages in the working population remains once account is taken of the differences between males and females in the mean value of regressors included in the econometric model of wages. ${ }^{3}$ Thus, measures of the gender wage gap range from 7 to 18 percent, with most estimates being between 12 and 14 percent. More recent

\footnotetext{
${ }^{2}$ These methods are explained in Section III.

${ }^{3}$ There is no obvious relationship between the gender wage gap reported in the Australian studies reviewed in Borland (1999) and macroeconomic conditions. However, this is an issue that might be analysed rigorously, through applying a common specification of the earnings function to crosssectional data sets collected at different points in the business cycle.
} 
studies have examined the effect of industrial relations reform on the gender wage gap in Australia, but have failed to reach a consensus on this issue (see Preston and Crockett (1999)).

The Australian studies to date have either analysed all workers (e.g., Miller 1994; Vella 1993; Reiman 1999) or have restricted their study to wage and salary earners (e.g., Kidd and Viney 1991; Preston and Crockett 1999). There is an absence of the comparative analysis of the gender wage differential across sectors of the labour market of the type undertaken in the study of the immigrant wage differential noted above, or in gender wage analyses conducted in the US (e.g., Hundley and Jacobson 1996). This void in the Australian literature is filled in the current study where the gender wage differentials for wage and salary earners and for the self-employed are analysed and compared. Comparisons across regulated and deregulated environments, as typified by the Australian and US labour markets, are also presented.

\section{THEORETICAL FRAMEWORK}

The theoretical framework is based on the Blinder (1973) decomposition. Blinder (1973) showed that if separate wage equations are estimated for males and females:

$$
\begin{aligned}
& \widehat{\ln Y}_{i m}=\hat{\beta}_{o m}+V_{i m} \hat{\beta}_{m} \\
& \widehat{\ln Y}_{i f}=\hat{\beta}_{o f}+V_{i f} \hat{\beta}_{f}
\end{aligned}
$$

where $\mathrm{m}$ and $\mathrm{f}$ denote males and females respectively, $\ln Y$ is the natural logarithm of hourly wages, $\beta_{0}$ is an intercept term, $V$ is a vector of characteristics assumed to affect wages, and $\beta$ is a vector of estimated slope coefficients, then the difference between the mean wages of males and females can be decomposed as:

$$
\overline{\ln Y}_{m}-\overline{\ln Y}_{f}=\left(\bar{V}_{m}-\bar{V}_{f}\right) \hat{\beta}_{m}+\bar{V}_{f}\left(\hat{\beta}_{m}-\hat{\beta}_{f}\right)+\left(\hat{\beta}_{o m}-\hat{\beta}_{o f}\right)
$$

The raw gender wage differential, $\left(\overline{\ln Y}_{m}-\overline{\ln Y}_{f}\right)$, is the difference in the mean value of the natural logarithm of the hourly wage rate of males and females. The first term on the right-hand side is the 'explained portion', which is the proportion of the gap that can be attributed to differences in individual characteristics. It is the difference in 
the mean values of wage determinants possessed by males and females evaluated according to the wage returns received by males. The second term is the 'unexplained' portion. It is the difference in the return to each wage determinant received by males and females, weighted according to the level of the wage determinant possessed by females. The third term is the difference in the constants. The last two terms are generally considered to be an indicator of the extent of discrimination. ${ }^{4}$

The basic Blinder decomposition assumes that the male wage structure is the nondiscriminatory norm. As an alternative, the female wage structure can be used as the non-discriminatory norm. The decomposition becomes:

$$
\overline{\ln Y}_{m}-\overline{\ln Y}_{f}=\left(\bar{V}_{m}-\bar{V}_{f}\right) \hat{\beta}_{f}+\bar{V}_{m}\left(\hat{\beta}_{m}-\hat{\beta}_{f}\right)+\left(\hat{\beta}_{o m}-\hat{\beta}_{o f}\right)
$$

Cotton (1988) argued that when discrimination exists the wage structure is distorted in two directions. First, males are paid a premium for their productivity characteristics as a result of nepotism. Second, females have their characteristics undervalued as a result of discrimination. He suggested estimating a non-discriminatory wage structure through a linear combination of the existing wage structures, with the resulting decomposition given by:

$\overline{\ln Y}_{m}-\overline{\ln Y}_{f}=\left(\bar{V}_{m}-\bar{V}_{f}\right) \beta^{*}+\bar{V}_{m}\left(\widehat{\beta}_{m}-\beta^{*}\right)+\bar{V}_{f}\left(\beta^{*}-\widehat{\beta}_{f}\right)+\left(\widehat{\beta}_{o m}-\widehat{\beta}_{o f}\right)$

where $\beta^{*}$ is the non-discriminatory wage structure which is computed as:

$\beta^{*}=\rho_{m} \widehat{\beta}_{m}+\rho_{f} \widehat{\beta}_{f}$

where $\rho_{m}$ is the proportion of the workforce that is male and $\rho_{f}$ is the proportion of the workforce that is female. The first term of the decomposition is the explained component. The second and third terms represent the male treatment advantage and

\footnotetext{
${ }^{4}$ The Blinder decomposition has a number of limitations. The more important of these concern the unavailability of detailed decompositions of the discrimination component when categorical variables have more than two categories (see Jones 1983), the absence of a unique non-discriminatory wage structure (discussed below), and the fact that the indicator of discrimination may also capture the impact of model mis-specification, omitted variables and measurement error. This latter issue may mean that the different outcomes for men and women may be a result of differences in the quality of labour that are not captured by the variables included in the analysis. The importance of this limitation cannot be quantified in this study.
} 
the female treatment disadvantage respectively. The last three terms are considered to be an indicator of the extent of discrimination.

Both the Blinder (1973) and Cotton (1988) decompositions are employed in this study. The average of the two Blinder (1973) decompositions outlined above is used in the presentations below.

\section{EMPIRICAL ANALYSIS: AUSTRALIA}

The data used to examine the determinants of earnings in the Australian labour market are from the 1991 Australian Census of Population and Housing, Household Sample File (HSF). The primary advantage of this data set is the large number of observations that allow a disaggregated analysis of earnings. The Census has information on an individual's education, potential experience, personal characteristics and job characteristics, including industry and occupation. The large sample is also advantageous because of the relatively small percentage of the labour force that are self-employed. In the $1991 \mathrm{HSF}, 18$ percent of the labour force were self-employed. Finally, the availability of comparable data for approximately the same time period from the 1990 US Census is also an argument in favour of the use of these data.

The basic model is an expanded version of Mincer's (1974) semi-logarithmic earnings equation that attributes differences in earnings to the level of education and experience. Statistical tests revealed the superiority of the semi-logarithmic specification over its linear counterpart, though in line with previous research, other function forms were not considered. Following the literature, the basic earnings equation was augmented with variables for occupation, industry and demographic characteristics. The variables for occupation and industry might account for short-run fluctuations in earnings caused by market imperfections (see Kidd and Shannon (1996) for a discussion of this approach). The demographic variables account for birthplace, marital status, the existence of dependent children and geographic location. These variables are generally included in studies of this type to proxy productivity differences (e.g., dependent children as a measure of time out of the labour force; birthplace as a reflection of differences in the quality of human capital). It is noted that even with this quite rich array of explanatory variables, the equations 
estimated account for only a little over one-third of the variation in (logarithmic) earnings for Australia, and a little less than one-third for the US. In other words, the description of the earnings determination process is far from complete. Ramsey's regression specification error test (with squared and cubed predicted values introduced into the earnings function as additional regressors) was applied to the models. This generated mixed evidence. For example, in the case of the disaggregated earnings models estimated for Australia (see Tables 1 and 2), two passed the test and two did not. Unfortunately, this test does not help in the choice of alternative models, particularly where the use of more encompassing models of the earnings determination process is limited by the variables collected in the Census. The implications of this are discussed in footnote 4.

The model estimated is ${ }^{5}$ :

$$
\begin{aligned}
& \ln Y=\beta_{0}+\beta_{1} \text { degree }+\beta_{2} \text { diploma }+\beta_{3} \text { cert }+\beta_{4} \text { hschool }+\beta_{5} \text { exp }+\beta_{6} \exp ^{2} \\
& +\beta_{7} \text { metro }+\beta_{8} \text { married }+\beta_{9} \text { wsd }+\beta_{10} \text { child }+\beta_{11} \text { engsp }+\beta_{12} \text { nengsp }+\beta_{13} \text { female } \\
& +\beta_{14} \text { manager }+\beta_{15} \text { prof }+\beta_{16} \text { paraprof }+\beta_{17} \text { trades }+\beta_{18} \text { clerks }+\beta_{19} \text { sales } \\
& +\beta_{20} \text { operator }+\beta_{21} \text { agric }+\beta_{22} \text { mining }+\beta_{23} \text { manuf }+\beta_{24} \text { civil }+\beta_{25} \text { const }+\beta_{26} \text { trade } \\
& +\beta_{27} \text { transp }+\beta_{28} \text { finance }+\beta_{29} \text { public }+\beta_{30} \text { community }+u
\end{aligned}
$$

The method of estimation is Ordinary Least Squares (OLS). Given the presence of heteroscedasticity, as detected by the significant Breusch-Pagan statistics reported in the tables of results, standard errors were computed using White's (1980) heteroscedasticity consistent covariance matrix estimator.

Most of the recent analyses of the gender wage differential in Australia focus on fulltime workers (Chapman and Mulvey 1986; Kidd and Viney 1991; Kidd 1993b; Kidd and Meng 1997; Wooden 1999). This practice is followed here. The restricted sample consists of 35,441 observations on full-time workers aged 20-64. The wage and salary sector has 28,691 observations with 18,975 males and 9,716 females. The selfemployment sector consists of 6,750 observations with 5,157 males and 1,593 females.

\footnotetext{
${ }^{5} \mathrm{~A}$ complete list of explanatory variables with detailed definitions is presented in Appendix A.
} 
It will be apparent from the use of this sample that there are three levels of sample selection. First, there is the decision to enter the paid labour market. This is quite important in the case of females, and there is a large literature that has attempted to quantify the important influences in this regard. Second, there is the decision to work full-time or part-time conditional upon labour market entry. Third, conditional upon being in the full-time labour market, there is the choice between sector of employment. Each of these decisions has been modelled in the literature, and these models can, in principle, be used with the Heckman (1979) procedure to correct the wage distributions studied for the non-random nature of the samples that generated them. However, even the studies using models of single decisions to correct for selfselection bias in analyses of the gender wage differential have produced conflicting results (Miller and Rummery 1991, Kidd and Viney 1991, Le 1998). This finding seems to arise because of weaknesses of the correction procedure (in particular its sensitivity to distribution assumptions and identification restrictions: see Puhani (2000) and Stolzenberg and Relles (1997)). ${ }^{6}$ As a result, application of this methodology may actually introduce more bias than it corrects (Le and Miller 1998, p.417). In the current study, as noted above, there are three inter-related choices that should be modeled. Given the problems that have emerged in the studies that have attempted to apply simple corrections derived from a single selection mechanism, no correction is attempted using the more complex selection mechanisms for the current set of analyses. ${ }^{7}$ While this means that selectivity bias may affect the analysis, the literature does not permit assessment of the magnitude or even the direction of any distortions to the analyses presented.

Initially the model was estimated for the entire sample and included a dummy variable for gender. The estimated coefficient on the female variable was negative and significant at the one percent level (-0.169), indicating that, with other measured

\footnotetext{
${ }^{6}$ Furthermore, it appears that the procedure is even more volatile when it is applied to the selfemployed (Le and Miller 1998).

${ }^{7}$ Lee and Miller (2003) show that in a model of the choice for male workers between wage and salaried employment and self-employment in Australia, both the sign and the magnitude of the coefficient on the sample selection term are sensitive to the specification of the model. While this does not affect the central findings of the Lee and Miller (2003) study, which has a focus on the coefficient on a schooling variable, changes of this nature would impact greatly on the current set of analyses, as they have the potential to impact on the relative magnitudes of the observed and offered wage distributions.
} 
determinants of wages held constant, on average women earn 17 percent less than males. $^{8}$ Estimating separate regressions for wage and salary earners and the selfemployed generated significant (at the one percent level) coefficients on the female variable of -0.141 and -0.196 , respectively, which suggests that the gender wage gap is greater among the self-employed.

Separate regressions were estimated for males and females in wage and salary employment and in self-employment. The regression results are displayed in Tables 1 and 2. These results show that the model performs better for males than for females, and better for paid employment than for self-employment. The performance of the model for wage and salary earners is consistent with similar studies (Preston 1997; Reiman 1999). The explanatory power of the model for the self-employed is also consistent with the little available evidence (Kidd 1993a, Le 1998), though there are no other studies that have specifically examined the earnings of females in the selfemployed sector. The most pertinent results are discussed below.

Educational attainment is an important determinant of earnings for wage and salary earners. The returns to education are positive and increase monotonically with the level of education. Males and females who have completed a degree earn 37 percent and 34 percent more, respectively, than those who did not finish high school. Males and females who graduated from high school both earn between 6 and 7 percent more than those who did not complete high school. The magnitude of these returns to education is consistent with those reported elsewhere (see, for example Preston 1997).

The effect of educational attainment on the earnings of the self-employed is remarkably different from that for wage and salary earners. Both males and females receive positive returns to a degree, but the coefficients on all other forms of education among the self-employed are statistically insignificant. This suggests that, excluding degrees, which are required by professionals such as doctors, the returns to other forms of education are zero. This supports the screening hypothesis, which proposes that education does not inherently improve productive capacity but provides

\footnotetext{
${ }^{8}$ In semi-logarithmic equations the coefficients on dummy variables which are small in value can be interpreted as the percentage effects on the dependent variable relative to the omitted category (Havorsen and Palmquist 1980).
} 
Table 1: OLS Estimates of Earnings by Gender: Australian Wage and Salary Workers, 1991

\begin{tabular}{|c|c|c|c|c|c|}
\hline \multicolumn{3}{|c|}{ Male Earnings: Wage \& Salary Workers } & \multicolumn{3}{|c|}{ Female Earnings: Wage \& Salary Workers } \\
\hline Variable & Coefficient & t-ratio & Variable & Coefficient & t-ratio \\
\hline $\begin{array}{l}\text { constant } \\
\text { Education }\end{array}$ & 1.808 & 101.63 & $\begin{array}{l}\text { constant } \\
\text { Education }\end{array}$ & 1.800 & 79.44 \\
\hline degree & 0.368 & 27.48 & degree & 0.337 & 20.70 \\
\hline diploma & 0.235 & 13.37 & diploma & 0.247 & 14.63 \\
\hline certificate & 0.132 & 15.59 & certificate & 0.133 & 10.29 \\
\hline high school & 0.059 & 7.30 & high school & 0.067 & 6.58 \\
\hline Experience & & & Experience & & \\
\hline experience (exp) & 0.021 & 21.62 & Experience (exp) & 0.023 & 18.02 \\
\hline $\exp ^{2} / 100$ & -0.036 & 17.13 & $\exp ^{2} / 100$ & -0.047 & 14.73 \\
\hline Demographic & & & Demographic & & \\
\hline metropolitan & 0.051 & 8.37 & metropolitan & 0.057 & 6.81 \\
\hline married & 0.086 & 11.38 & married & 0.000 & 0.05 \\
\hline wsd & 0.044 & 3.88 & wsd & 0.040 & 3.61 \\
\hline child & 0.017 & 2.78 & child & -0.075 & 9.10 \\
\hline engsp & 0.017 & 2.16 & engsp & 0.016 & 1.45 \\
\hline nengsp & -0.059 & 7.28 & nengsp & -0.021 & 1.93 \\
\hline Occupation & & & Occupation & & \\
\hline manager & 0.381 & 30.60 & manager & 0.374 & 17.16 \\
\hline professional & 0.330 & 24.83 & professional & 0.356 & 19.79 \\
\hline paraprofessional & 0.301 & 27.16 & paraprofessional & 0.301 & 16.77 \\
\hline trades & 0.119 & 12.77 & trades & 0.068 & 2.57 \\
\hline clerks & 0.194 & 18.36 & clerks & 0.216 & 15.26 \\
\hline sales & 0.175 & 14.21 & sales & 0.122 & 7.48 \\
\hline operator & 0.077 & 7.99 & operator & 0.001 & 0.02 \\
\hline Industry & & & Industry & & \\
\hline agriculture & -0.235 & 8.13 & agriculture & -0.480 & 5.72 \\
\hline mining & 0.521 & 23.29 & mining & 0.317 & 7.66 \\
\hline manufacturing & 0.143 & 9.74 & manufacturing & 0.089 & 5.05 \\
\hline civil & 0.274 & 14.77 & civil & 0.126 & 1.87 \\
\hline construction & 0.173 & 10.37 & construction & 0.083 & 2.16 \\
\hline trade & 0.060 & 4.08 & trade & 0.019 & 1.11 \\
\hline transport & 0.166 & 10.51 & transport & 0.119 & 5.27 \\
\hline finance & 0.221 & 13.10 & finance & 0.148 & 8.43 \\
\hline public & 0.193 & 12.39 & public & 0.142 & 7.01 \\
\hline community & 0.083 & 5.19 & community & 0.064 & 3.73 \\
\hline \multicolumn{3}{|c|}{ Mean of $\ln Y=2.572$} & \multicolumn{3}{|c|}{ Mean of $\ln Y=2.440$} \\
\hline \multirow{2}{*}{\multicolumn{3}{|c|}{$\begin{array}{l}\text { Number of Observations }=18975 \\
\text { Breusch-Pagan Chi-Squared }=1916.27\end{array}$}} & \multicolumn{3}{|c|}{ Number of Observations $=9716$} \\
\hline & & & \multicolumn{3}{|c|}{ Breusch-Pagan Chi-Squared $=1866.49$} \\
\hline \multicolumn{3}{|c|}{$F(29,18945)=363.84$} & $F(29,9686)=1$ & & \\
\hline \multicolumn{3}{|c|}{ Adjusted $R^{2}=0.357$} & \multicolumn{3}{|c|}{ Adjusted $R^{2}=0.333$} \\
\hline
\end{tabular}


Table 2: OLS Estimates of Earnings by Gender: Australian Self-Employed Workers, 1991

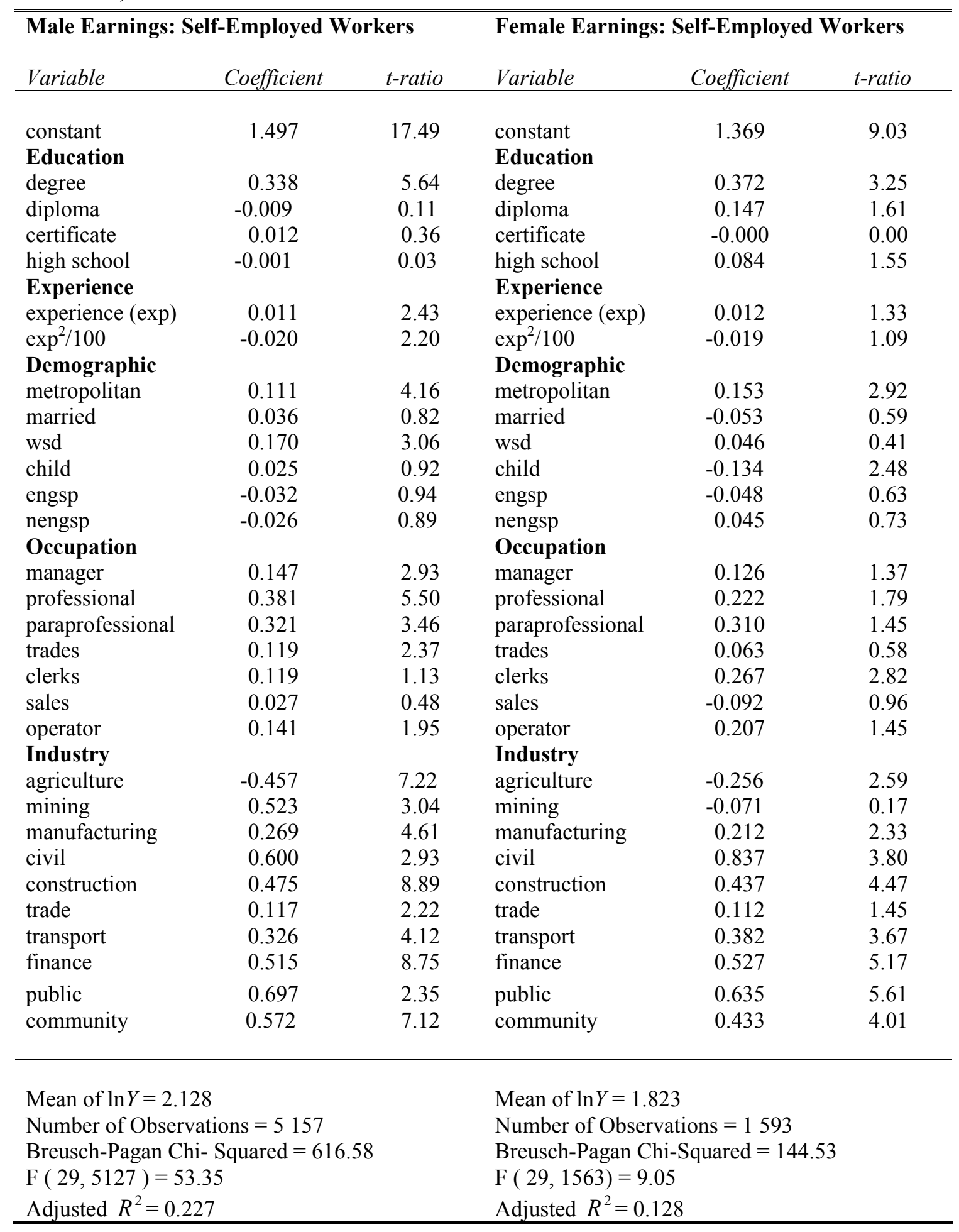


employers with a signal of pre-existing abilities. In this case, workers in the wage and salary sector are 'screened' by employers through educational qualifications and therefore receive a return to education. Conversely, the self-employed are 'unscreened' and therefore do not receive a return to education (see also Lee and Miller 2003).

The results in Tables 1 and 2 indicate that experience has a positive impact on earnings across gender and sector of employment. An additional year of labour market experience increases the earnings of both male and female wage and salary earners by about 1.4 percent (evaluated at ten years of experience). The corresponding rates of return among the self-employed were 0.7 percent and 0.8 percent.

Marital status and the presence of dependent children are also important determinants of earnings. Among wage and salary earners, married males have higher earnings than their single counterparts while marriage does not affect the earnings of females. These results are consistent with findings reported by Chapman and Mulvey (1986), Kidd and Viney (1991), and Langford (1995). In relation to children, while women who have dependent children earn 7.5 percent less than those who do not, males with dependent children have slightly higher earnings.

Interestingly, the earnings of married males and females in self-employment are not significantly different from the earnings of their single counterparts. However, dependent children are associated with 13.4 percent lower earnings for females, while males with dependent children have 2.5 percent higher earnings.

Australian empirical literature has shown the earnings performance of immigrants to be mixed, with those born in an English-speaking country having higher earnings than the native born, while those from a non-English-speaking country have lower earnings than the native born (Chapman and Mulvey 1986; Preston 1997; Reiman 1999). The estimated coefficients on the birthplace variables among wage and salary earners are 
consistent with the literature. In contrast, birthplace does not affect earnings among the self-employed. ${ }^{9}$

The results of the Blinder (1973) decomposition for wage and salary earners in the Australian labour market are presented in Table $3 .{ }^{10}$ The raw gender wage differential among wage and salary earners is 13.15 percentage points. The decomposition reveals that differences in productivity characteristics serve to reduce rather than widen the wage gap. ${ }^{11}$ The adjusted wage gap is 0.1559 which indicates that, when account is taken of gender differences in the regressors included in the model of earnings, the average female earns 15.59 percent less than the average male.

Table 3: Decomposition of the Gender Wage Differenital, Australian Wage and Salary Workers, 1991

\begin{tabular}{llrlll}
\hline Variables & $\begin{array}{l}\text { Raw Wage } \\
\text { Differential }\end{array}$ & $\begin{array}{l}\text { Explained } \\
\text { Proportion }\end{array}$ & $\begin{array}{l}\text { Unexplained } \\
\text { Proportion }\end{array}$ & $\begin{array}{l}\text { Difference in } \\
\text { Constants }\end{array}$ & $\begin{array}{l}\text { Adjusted } \\
\text { Wage } \\
\text { Gap }\end{array}$ \\
\hline Education & & -0.0052 & & & \\
Experience & & 0.0144 & & & \\
Demographic & & -0.0023 & & & \\
Occupation & & -0.0397 & & & \\
Industry & & 0.0083 & $\mathbf{0 . 0 0 7 2}$ & $\mathbf{0 . 1 5 5 9}$ \\
TOTAL & $\mathbf{0 . 1 3 1 5}$ & $\mathbf{- 0 . 0 2 4 4}$ & $\mathbf{0 . 1 4 8 7}$ & $\mathbf{0 . 0 0 1 6}$ \\
\hline
\end{tabular}

Note: the various breakdowns may not sum due to rounding errors. All figures should be multiplied by 100 to obtain percentage point effects.

The raw wage differential for the self-employed is 30.46 percentage points, which is more than twice that among wage and salary earners. A decomposition of this wage differential is presented in Table 4. The decomposition shows that 10.02 percentage points, or 33 percent of the differential, is accounted for by differences in human

\footnotetext{
${ }^{9} \mathrm{~F}$ tests revealed that the industry and occupation variables were significant as groups. The results are broadly consistent with findings from similar studies (Chapman and Mulvey 1986; Kidd and Viney 1991; Langford 1995; Preston 1999; Reiman 1999) and will not be discussed.

${ }^{10}$ More detail is shown for the explained portion of the gender wage differential than for the unexplained portion for the reasons presented in Jones (1983).

${ }^{11}$ This is based on the average of the two Blinder decompositions outlined above. Using the male wage structure as the non-discriminatory norm results in an adjusted wage gap of 0.1237 ; using the female wage structure as the non-discriminatory norm results in an adjusted wage gap of 0.1882 . The Cotton (1988) decomposition also gives a slight negative explained component, indicating that the gap would be higher under a non-discriminatory wage structure. The unexplained component was 0.1453 , of which 44 percent was due to the male treatment advantage and 56 percent was due to the female treatment disadvantage.
} 
capital, leaving an unexplained component of 20.44 percentage points, or 67

percent. $^{12}$

Table 4: Decomposition of the Gender Wage Differential, Australian Self-Employed Workers, 1991

\begin{tabular}{llclll}
\hline Variables & $\begin{array}{l}\text { Raw Wage } \\
\text { Differential }\end{array}$ & $\begin{array}{l}\text { Explained } \\
\text { Proportion }\end{array}$ & $\begin{array}{l}\text { Unexplained } \\
\text { Proportion }\end{array}$ & $\begin{array}{l}\text { Difference in } \\
\text { Constants }\end{array}$ & $\begin{array}{l}\text { Adjusted } \\
\text { Wage } \\
\text { Gap }\end{array}$ \\
\hline Education & & 0.0097 & & & \\
Experience & & -0.0038 & & & \\
Demographic & & 0.0060 & & & \\
Occupation & & 0.0043 & & & \\
Industry & & 0.0840 & & $\mathbf{0 . 1 2 7 2}$ & $\mathbf{0 . 2 0 4 4}$ \\
TOTAL & $\mathbf{0 . 3 0 4 6}$ & $\mathbf{0 . 1 0 0 2}$ & $\mathbf{0 . 0 7 7 2}$ & $\mathbf{0 7 2}$
\end{tabular}

Note: the various breakdowns may not sum due to rounding errors. All figures should be multiplied by 100 to obtain percentage point effects.

A comparison of the adjusted wage gaps reveals a positive difference between wage and salary earners $(0.1559)$ and the self-employed $(0.2044)$ of 4.85 percentage points. That is, the gender wage gap is greater among the self-employed. As part of the incomes of the self-employed may reflect returns on capital, this greater adjusted gender wage gap for this group could arise where females have greater difficulty than males in capital markets. Other factors that might have an influence include different motivations across sectors (e.g., income maximisation versus combining market work via self employment with home duties), and the absence of regulation of wage outcomes among the self employed.

\section{EMPIRICAL ANALYSIS: UNITED STATES}

While the United States labour market shares many characteristics with the Australian market, a major difference is the institutional arrangements for wage determination, with the United States market being far less regulated. Consequently, the United States provides a useful comparison that can be used to explore the impact of regulation on the Australian gender wage gap. This section presents an examination of the relative earnings of women in wage and salaried employment and in selfemployment in the United States. The analysis parallels the Australian framework presented in the previous section.

\footnotetext{
${ }^{12}$ The raw wage differential was also decomposed using the Cotton (1988) method and the unexplained portion increased to 0.1914 . Of the unexplained component, 38 percent was due to the male treatment advantage and 62 percent was due to the female treatment disadvantage.
} 
The data are from one percent Public Use Microdata File of the 1990 United States Census. ${ }^{13}$ For comparative purposes the sample is restricted to full-time employed persons aged 20-64. The resulting sample consists of 743,089 observations with 663,160 observations from the wage and salary sector and 79,929 from the selfemployed sector.

In order to make comparisons with the results for the Australian labour market, the model of earnings for the United States was derived to reflect the specification adopted for the Australian data as closely as possible. Variation in the census data and accounting for differences in demographic characteristics required some minor modifications to the model. ${ }^{14}$ Analyses of earnings in the United States have revealed that those who are black by race experience an earnings disadvantage relative to other racial groups (Chiswick and Miller, 1998a). ${ }^{15}$ It has also been found that individuals in southern states typically experience lower levels of income (Chiswick and Miller, 1998a). Therefore, geographic and race variables were included in the model. In regard to immigrants, Chiswick and Miller (1998b) have found that, contrary to the situation in Australia, the earnings of immigrants in the United States are affected by the number of years since migration. Thus, a variable was included in the model to capture the impact of years since migration on earnings.

The earnings equation was first estimated for the entire sample. The coefficient on the female variable was a highly significant -0.258 , indicating that when the other determinants of earnings able to be included in the estimating equation are held constant, women earn 26 percent less than men. The earnings equations were then estimated for males and females in wage and salaried employment and in self-

\footnotetext{
${ }^{13}$ As this sample is non-random, all data are used in weighted form.

${ }^{14}$ A complete list of explanatory variables and their detailed definition are set out in Appendix B.

${ }^{15}$ It has been found that Indigenous Australians suffer a greater earnings disadvantage than those of black racial origin in the United States (Taylor 1993, p.39). The small percentage of Aboriginal persons in the Australian sample prevented their inclusion in the analysis. However, considering the small number of observations it is unlikely that the inclusion of a race variable would have a major impact on the results.
} 
Table 5: OLS Estimates of Earnings by Gender: United States Wage and Salary Workers, 1990

\begin{tabular}{|c|c|c|c|c|c|}
\hline \multicolumn{3}{|c|}{ Male Earnings: Wage \& Salary Workers } & \multicolumn{3}{|c|}{ Female Earnings: Wage \& Salary Workers } \\
\hline Variable & Coefficient & t-ratio & Variable & Coefficient & t-ratio \\
\hline $\begin{array}{l}\text { Constant } \\
\text { Education }\end{array}$ & 1.339 & 253.91 & $\begin{array}{l}\text { constant } \\
\text { Education }\end{array}$ & 1.378 & 186.90 \\
\hline degree & 0.552 & 150.48 & degree & 0.504 & 111.69 \\
\hline diploma & 0.300 & 57.85 & diploma & 0.296 & 50.82 \\
\hline certificate & 0.264 & 85.77 & certificate & 0.214 & 54.72 \\
\hline high school & 0.168 & 59.23 & high school & 0.116 & 31.97 \\
\hline \multicolumn{3}{|l|}{ Experience } & Experience & & \\
\hline experience (exp) & 0.045 & 144.57 & experience (exp) & 0.033 & 96.31 \\
\hline $\exp ^{2} / 100$ & -0.067 & 104.28 & $\exp ^{2} / 100$ & -0.055 & 75.33 \\
\hline $\begin{array}{l}\text { Demographic } \\
\text { rural } \\
\text { south }\end{array}$ & $\begin{array}{l}-0.074 \\
-0.127\end{array}$ & $\begin{array}{l}36.08 \\
70.61\end{array}$ & $\begin{array}{l}\text { Demographic } \\
\text { rural } \\
\text { south }\end{array}$ & $\begin{array}{l}-0.111 \\
-0.107\end{array}$ & $\begin{array}{l}46.98 \\
54.10\end{array}$ \\
\hline married & 0.174 & 71.65 & married & 0.029 & 10.58 \\
\hline wsd & 0.049 & 13.94 & wsd & 0.016 & 5.02 \\
\hline child & - & - & child & -0.057 & 25.25 \\
\hline black & -0.096 & 30.61 & black & 0.016 & 5.15 \\
\hline Engsp & -0.055 & 5.96 & engsp & -0.003 & 0.32 \\
\hline Nengsp & -0.215 & 45.95 & nengsp & -0.096 & 16.44 \\
\hline \multirow{2}{*}{\multicolumn{3}{|c|}{ Occupation }} & \multirow{2}{*}{\multicolumn{3}{|c|}{ Occupation }} \\
\hline & & & & & \\
\hline Manager & 0.307 & 86.79 & manager & 0.290 & 53.11 \\
\hline professional & 0.272 & 69.52 & professional & 0.309 & 52.46 \\
\hline paraprofessional & 0.205 & 47.13 & paraprofessional & 0.256 & 40.03 \\
\hline trades & 0.134 & 48.07 & trades & 0.121 & 16.87 \\
\hline clerks & 0.062 & 16.76 & clerks & 0.104 & 20.75 \\
\hline sales & 0.187 & 45.65 & sales & 0.115 & 18.70 \\
\hline service & -0.016 & 4.14 & service & -0.112 & 19.34 \\
\hline operator & 0.030 & 7.38 & operator & -0.074 & 11.99 \\
\hline agfofish & -0.123 & 13.54 & agfofish & -0.078 & 3.88 \\
\hline \multicolumn{3}{|l|}{ Industry } & \multicolumn{3}{|l|}{ Industry } \\
\hline agriculture & -0.084 & 8.98 & agriculture & -0.046 & 3.15 \\
\hline mining & 0.270 & 32.77 & mining & 0.305 & 18.00 \\
\hline manufacturing & 0.192 & 50.36 & manufacturing & 0.184 & 38.35 \\
\hline civil & 0.274 & 49.03 & civil & 0.330 & 32.19 \\
\hline construction & 0.160 & 35.31 & construction & 0.157 & 18.09 \\
\hline trade & -0.003 & 0.71 & trade & -0.037 & 7.66 \\
\hline transport & -0.212 & 46.41 & transport & 0.290 & 49.03 \\
\hline finance & 0.182 & 32.73 & finance & 0.166 & 34.15 \\
\hline public & 0.043 & 9.61 & public & 0.164 & 30.77 \\
\hline community & -0.005 & 1.22 & community & 0.073 & 16.37 \\
\hline \multicolumn{3}{|c|}{ Mean of $\ln Y=2.421$} & \multicolumn{3}{|c|}{ Mean of $\ln Y=2.134$} \\
\hline \multicolumn{3}{|c|}{ Number of Observations $=445,02$} & \multicolumn{3}{|c|}{ Number of Observations $=318,135$} \\
\hline \multicolumn{3}{|c|}{ Breusch-Pagan Chi-Squared $=14348.7$} & \multicolumn{3}{|c|}{ Breusch-Pagan Chi-Squared $=8519.5$} \\
\hline \multicolumn{3}{|c|}{$\mathrm{F}(34,444,991)=6378.0$} & \multicolumn{3}{|c|}{$\mathrm{F}(35,318,099)=3452.7$} \\
\hline \multicolumn{3}{|c|}{ Adjusted $R^{2}=0.321$} & \multicolumn{3}{|c|}{ Adjusted $R^{2}=0.269$} \\
\hline
\end{tabular}


Table 6: OLS Estimates of Earnings by Gender: United States Self-Employed Workers, 1990

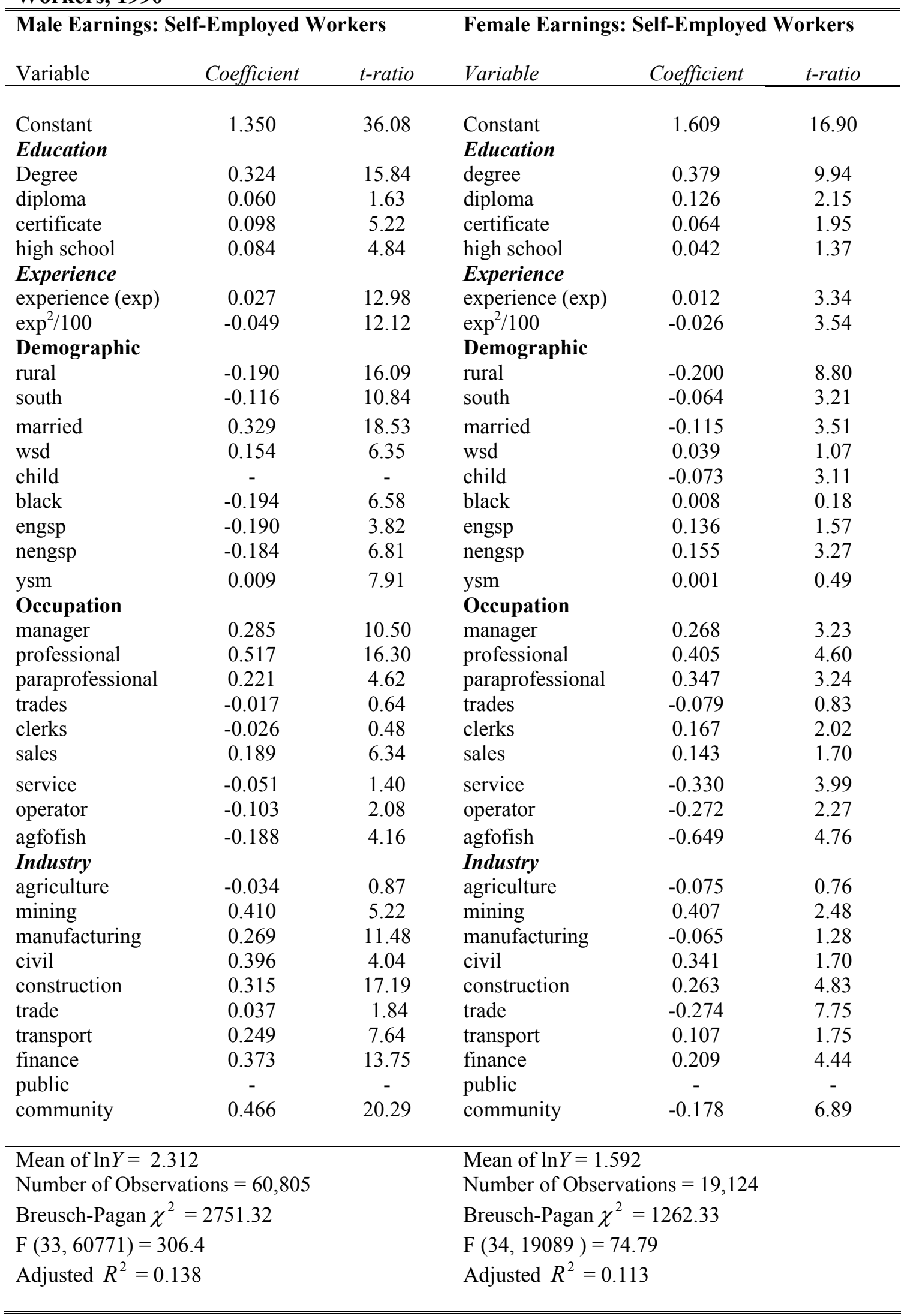


employment. The results are presented in Tables 5 and 6 . The estimated coefficients were broadly consistent with other studies (see, for example, Gregory and Daly (1992) or Chiswick and Miller (1998a) for wage and salary earners). As a result, an in-depth examination of the results will not be presented here. However, several notable findings will be discussed.

Educational attainment and experience have positive impacts among wage and salary earners. Moreover, the returns to human capital are higher in the United States than in Australia. In particular, males receive relatively large returns to high school (17 percent in the United States versus 6 percent in Australia). Among the self-employed the returns to education are generally statistically significant, but are much smaller than among wage and salary earners.

Demographic characteristics have a significant impact on earnings, and the majority of the estimated coefficients are consistent with a priori expectations. An exception to this is in wage and salary employment, where males of black racial origin incur an earnings disadvantage of -9.6 percent, while females have a small earnings advantage compared to their white counterparts. This situation is replicated among the self-employed.

The raw wage differential among wage and salary earners is 0.29 . The result is consistent with the international literature which has found that a wage differential of approximately 0.30 exists in countries with relatively lower levels of labour market regulation, such as the United States and the United Kingdom (Gregory 1999). The decomposition of the wage differential among wage and salary earners is presented in Table 7.

The decomposition reveals an explained component of 0.0349 (or 12 percent) of the raw differential. After accounting for differences in human capital endowments, an adjusted wage gap of 0.2519 exists. Therefore, when account is taken of gender differences in the explanatory variables listed in Tables 5 and 6 using Blinder's 
methodology, female wage and salary earners earn, on average, 25 percent less than males. $^{16}$

Table 7: Decomposition of the Gender Wage Differential, United States Wage and Salary Workers, 1990

\begin{tabular}{lccccl}
\hline Variables & $\begin{array}{l}\text { Raw Wage } \\
\text { Differential }\end{array}$ & $\begin{array}{l}\text { Explained } \\
\text { Proportion }\end{array}$ & $\begin{array}{l}\text { Unexplained } \\
\text { proportion }\end{array}$ & $\begin{array}{l}\text { Difference in } \\
\text { Constants }\end{array}$ & $\begin{array}{l}\text { Adjusted } \\
\text { Wage } \\
\text { Gap }\end{array}$ \\
\hline Education & & -0.0060 & & & \\
Experience & & 0.0055 & & & \\
Demographic & & 0.0184 & & & \\
Occupation & & -0.0109 & & & \\
Industry & & 0.0280 & & $\mathbf{0 . 0 3 8 9}$ & $\mathbf{0 . 2 5 1 9}$ \\
TOTAL & $\mathbf{0 . 2 8 6 8}$ & $\mathbf{0 . 0 3 4 9}$ & $\mathbf{0 . 2 9 0 8}$ & $\mathbf{- 0 . 0 3 8}$ \\
\hline
\end{tabular}

Note: the various breakdowns may not sum due to rounding errors. All figures should be multiplied by 100 to obtain percentage point effects.

The raw wage differential for the self-employed is 0.72 . The substantial size of the differential was somewhat unexpected, but it is actually at the lower end of the limited evidence available elsewhere. For example, Hundley and Jacobson (1996) reported a differential of 1.36 using data from 1984. The decomposition of the wage differential presented in Table 8 reveals that 0.0763 (or 10.6 percent) of the raw differential is explained by differences in human capital, leaving an adjusted wage gap of 0.6444. This indicates that, after accounting for gender differences in the variables able to be included in the estimating equation using the Blinder decomposition, women in selfemployment earn, on average, 64 percent less than self-employed males.

Table 8: Decomposition of the Gender Wage Differential, United States Self-Employed Workers, 1990

\begin{tabular}{llclll}
\hline Variables & $\begin{array}{l}\text { Raw Wage } \\
\text { Differential }\end{array}$ & $\begin{array}{l}\text { Explained } \\
\text { Proportion }\end{array}$ & $\begin{array}{l}\text { Unexplained } \\
\text { proportion }\end{array}$ & $\begin{array}{l}\text { Difference in } \\
\text { Constants }\end{array}$ & $\begin{array}{l}\text { Adjusted } \\
\text { Wage } \\
\text { Gap }\end{array}$ \\
\hline Education & & 0.0231 & & & \\
Experience & & 0.0014 & & & \\
Demographic & & 0.0069 & & & \\
Occupation & & 0.0534 & & & \\
Industry & & -0.0085 & & & \\
TOTAL & $\mathbf{0 . 7 2 0 7}$ & $\mathbf{0 . 0 7 6 3}$ & $\mathbf{0 . 9 0 2 9}$ & $\mathbf{- 0 . 2 5 8 6}$ & $\mathbf{0 . 6 4 4 4}$ \\
\hline
\end{tabular}

Note: the various breakdowns may not sum due to rounding errors. All figures should be multiplied by 100 to obtain percentage point effects.

\footnotetext{
${ }^{16}$ The raw wage differential was also decomposed using the Cotton (1988) method. The explained portion was 0.037 , leaving an adjusted wage gap of 0.2498 .
} 
Tables 7 and 8 reveal that a large proportion of the gender wage differential in both sectors is attributable to differences in constants. The constant term can be considered as an indicator of the base level wage. It appears that women in the United States receive substantially lower base level wages than males, and a significant portion of the gender wage differential can be attributed to the lower basic wage received by women. This is in stark contrast to the Australian results where there was little variation across constant terms for wage and salary earners. Base level wages in Australia were roughly equal because the award system sets equal minimum wages. This may indicate that the adverse consequences of a deregulated labour market are most pronounced for those women at the lower end of the wage distribution. Several studies have found evidence to support that this is the case in the United Kingdom and the United States (Gregory 1999, p.277).

There are two major conclusions that can be drawn.

First, the empirical analysis for Australia found that the adjusted gender wage gap is significantly larger for the self-employed than among wage and salary earners. The award system governing outcomes among wage and salary earners in Australia appears to have offered females some degree of wage protection and has resulted in more equitable earnings.

Second, the empirical analysis for the United States found that the gender wage gaps were more than double those existing in Australia. ${ }^{17}$ The results show that the female wage disadvantage is greater in a deregulated environment, with females in selfemployment experiencing a proportionally greater disadvantage than those in Australia.

\section{CONCLUSION}

This paper estimated models of earnings in which wage variations were attributed to human capital endowments, demographic characteristics and structural factors (e.g, industry and occupation). Separate estimates were obtained for males and females in

\footnotetext{
17 The results for the United States cannot be directly transposed as potential outcomes in Australia because of country specific differences such as variation in industry and occupational distribution and social and cultural effects.
} 
wage and salary employment and in self-employment for Australia and the United States.

The estimated coefficients for wage and salary earners were consistent with the predictions of theory, namely that education and experience increase earnings capacity. The model was found to be empirically robust across countries, and the estimated coefficients were consistent with the results from earlier studies.

The model was also empirically robust for the self-employed across countries. However, education, with the exception of degrees, is not a significant determinant of earnings among the self-employed in Australia. This result supports the screening hypothesis that, at least in part, education does not inherently improve productive capacity but is used by employers as a signal of pre-existing abilities. In the United States labour market, while there is a positive relationship between educational attainment and earnings in the self-employed sector, the increments in earnings due to education are much lower than in the wage and salary sector.

The empirical analysis of Australia found that the gender wage gap is greater in the self-employed sector. Several reasons for this were advanced: liquidity constraints in the self-employed sector that affect men and women differently, differences across sectors in the extent to which income maximisation is the primary motive versus combining market work via self employment with home duties, and the absence of regulation of wage outcomes in the self-employed sector. To the extent that this final factor is important, the findings suggest that the gender wage gap will widen in a deregulated environment.

The empirical analysis of the United States found that the gender wage gap was more than double that in Australia. In a deregulated environment, women experience significantly lower relative earnings, with those in self-employment suffering a more pronounced disadvantage. Thus, as a general result, it appears that the more deregulated the system of wage determination the greater the gender inequality. 
These results can be used in a number of ways. First, the large gender wage gap for the self-employed means that the aggregate gender wage differential will not be closed simply by means of award determination for wage and salary sector earners.

Second, the greater gender wage gap for the self-employed than for those in wage and salary employment may reflect liquidity constraints which are more difficult for selfemployed women to overcome relative to self-employed men.

Third, the findings of this study are consistent with the hypothesis that the Australian gender wage differential will deteriorate under enterprise bargaining (see also Preston and Crockett (1999b), Whitehouse (1992) and Reiman (1999)). The expected widening of the gender wage differential under enterprise bargaining may not, however, be uniform for all women. The empirical analysis of the United States found that it is those women at the lower end of the wage distribution who experience the greatest disadvantages in a deregulated environment. This not only has implications for gender equity but also has important ramifications for health, welfare and community policy. 


\section{APPENDIX A}

\section{A. The Australian Data}

The variables used in the statistical analysis of the Australian Census are defined below. The Census mnemonic names used in the construction of variables are in parentheses (see Australian Bureau of Statistics 1994).

Dependent Variable

Log of Hourly Earnings (INCP; HRSP): The dependent variable is the natural logarithm of hourly earnings (where earnings are defined as gross earnings from all sources). As income was coded in intervals, midpoints were used to construct a continuous measure. The open-ended upper category was assigned a value of 1.5 times the lower threshold level. Weekly hours were recorded in intervals so midpoints were used to construct a continuous measure. Adjustments were made to reflect the fact that in the $41+$ hours category men work more hours than women (Labour Force Statistics, August 1991 p.22). The resulting mean hours for males and females were 44.67 and 40.50 , respectively. Hourly income was then constructed by dividing annual income by annual hours worked.

Explanatory Variables

Educational Attainment (QLLP; ALSP): Four education variables were constructed and are defined as:

degree: Higher Degree, Post Graduate Diploma or Bachelor Degree

diploma: Undergraduate Diploma

cert: Associate Diploma, Skilled Vocational and Basic Vocational Diploma

hschool: Completed high school (those who left school $16+$ were assumed to have completed high school)

Experience (AGEP; ALSP; QLLP): The experience variable was derived using the Mincer Proxy; Age - Schooling - 5. Age was recorded continuously from 0-24 and then recorded in intervals of five from 25-64. The midpoint of each band was used to construct a continuous measure. Years of schooling were determined using the age left school variable (ALSP). Additional years of education were estimated by assigning each qualification an estimated number of years that it would take to complete.

Birthplace (BPLP): The birthplace classifications from the Census were regrouped to distinguish between those immigrants born in an English-speaking country and those from a non-English-speaking country. Countries classified as English-speaking are: UK and Ireland, New Zealand, US and North America. All other countries are classified as non-English-speaking countries. Those born in Australia form the omitted category.

Marital Status (MSTP): Two variables were created to distinguish between those who are married and those who are widowed, separated or divorced (wsd). Those who were never married formed the omitted category.

Child (CDPF): This is a dichotomous variable set to one if an individual has dependent children and zero otherwise. 
Geographic Location (GDHSF91): A binary variable was created to distinguish between those who reside in a metropolitan area and those residing in nonmetropolitan areas. The metropolitan area is defined as: Inner Sydney, Sutherland and Liverpool, outer south west New South Wales, lower north New South Wales, Hunter and Illawarra, western outer Melbourne, central Melbourne, east outer Melbourne, Brisbane, Adelaide or Perth

Gender (SEXP): This is a binary variable set to one if an individual is female and zero if individual is male.

Occupation (OCCUP): The categorical Census information on Occupation were regrouped to form eight occupational categories. The categories are defined as follows:

\section{Occupation}

1 Manager/Administrators

2 Professionals

3 Paraprofessionals

4 Tradespersons

5 Clerks

6 Sales Representatives/Assistants, Personal Services

7 Plant/Machine Operators

8 Labourers (omitted category)

\section{Codes}

Industry (INDP): The categorical Census information on Industry were regrouped to form eleven industry groups. The eleven industry categories can be defined as:

\section{Industry \\ Content of Categories \\ Codes}

Agriculture/Services, Forestry/Logging, Fishing/Hunting Minerals, Coal/Oil/Gas, Construction Material

2 Mining

3 Manufacture Foor

$$
\text { Food/Beverages/Tobacco, Textiles/Wood/Paper Products, }
$$
Chemical/Mineral Products, Transport/Machine Equipment

4 Civil Electricity/Gas, Water, Sewerage/Drainage

5 Construction General/Special Construction

6 Trade

7 Transport

Wholesale/Retail Trade

Ground/Water/Air Transport, Storage, Communication

Finance/Investment, Property/Business/Insurance

Public Administration, Defence

9 Public

10 Community

11 Services

$1-4$

5-10

$11-22$

23-24

$25-26$

$27-28$

29-36

37-39

40-41

42-45 


\section{B. The United States Data}

The variables used in the statistical analysis of the United States are defined below. The Mnemonic names used in the construction of variables are in parentheses (see Bureau of Census 1992).

\section{Dependent Variable:}

Log of Hourly Earnings (INCOME; WEEK89; HOUR89): The dependent variable is the natural logarithm of hourly earnings. In order to construct the dependent variable annual income was divided by annual hours worked.

\section{Explanatory Variables:}

Educational Attainment (YEARSCH): Four education variables were constructed and are defined as follows:

degree: Doctorate, Professional, Masters or Bachelor Degree;

diploma: Associate Degree (academic/professional)

cert: Associate Degree (Occupational), College (No Degree)

hschool: High school graduate, diploma or GED.

Experience (AGE; YEARSCH): The experience variable was derived using the Mincer Proxy; Age - Schooling - 5.

The schooling variable was created by assigning each level of educational attainment an estimated number of years for completion.

Birthplace (POB): The birthplace classifications from the 1990 US Census were regrouped to distinguish between those immigrants born in an English-speaking country and those from a non-English-speaking country. Countries that are classified as English-speaking are: UK and Ireland, Canada, Australia, and the Caribbean. All other countries are classified as non-English-speaking countries. Those individuals born in the United States form the benchmark group.

Years Since Migration (IMMIGR): The Census responses were converted to a continuous measure using the following values: 1987-1990 (1.75 years); 1985-1986 (4.25 years); $1982-1984$ (6.15 years); 1980-1981 (9.25); 1977-1979 (12.75); 19701974 (17.75); 1965-1969 (22.5 years); 1950-1959 (32.25 years); before 1950 (49.75).

Race (RACE): This is a dichotomous variable set to one if the individual is African American and set to zero for all other racial groups.

Geographic Location (RFARM; STATE): The location variables record those who reside in a rural area or a Southern State.

Gender (SEX): This is a binary variable set to one if an individual is female and zero if individual is male.

Marital Status (RSPOUSE): Two variables were created to distinguish between those who are married and those who are widowed, separated or divorced (wsd). Those who were never married formed the omitted category. 
Child (RAGECHILD): This variable is only defined for females. It is a dichotomous variable set to one if a female has dependent children and zero otherwise.

Occupation (OCCUP): The categorical Census information on Occupation was regrouped to form ten occupational categories. The categories are defined as follows:

\section{Occupation}

1 Manager/Administrators

2 Professionals

3 Paraprofessionals

$4 \quad$ Sales Representatives/Assistants

5 Clerks

6 Service

7 Agriculture/Forestry/Fishing

8 Tradespersons

9 Plant/Machine Operators

10 Labourers (omitted category)

\section{Codes}

$(503-699,904,905)$

$(703-779)$

(783-889)

Industry (IND): The categorical Census information on Industry were regrouped to form eleven industry categories. The eleven industry categories can be defined as:

\section{Industry}

1 Agriculture

2 Mining

3 Construction

4 Manufacturing

5 Transport

6 Civil

7 WRTrade

8 Finance

9 Service (omitted category)

10 Community

11 Public

\section{Codes}

(400-450)

(450-500)

(500-700)

(700-720)

(721-812)

(812-900)

(900-960)

The contents of each industry category are identical to those defined in the Australian data with the exception of the community and service industries that include some forms of business services. 


\section{REFERENCES}

Australian Bureau of Statistics (1994). 1991 Census of Population and Housing Sample File (computer file), Australian Bureau of Statistics, Canberra.

Blinder, A. (1973). "Wage Discrimination: Reduced Form and Structural Estimates", Journal of Human Resources, Vol. 8(Winter), pp. 436-55.

Borland, J. (1999). “The Equal Pay Case - Thirty Years On”, Australian Economic Review, Vol. 32(3), pp. 265-272.

Bureau of Census (1992) Census of Population and Housing 1990, Public Use Microdata Samples US (machine-readable data files) prepared by the Bureau of Census, Washington.

Chapman, B. J. and Mulvey, C. (1986). "An Analysis of the Origins of Sex Differences in Australian Wages", Journal of Industrial Relations, 28(December), pp. 504-520.

Chiswick, B. and Miller, P.W. (1998a). "The Economic Cost to Native-Born Americans of Limited English Language Proficiency", Report Prepared for the Centre of Equal Opportunity.

Chiswick, B. and Miller, P.W. (1998b). "English Language Proficiency Among Immigrants in the United States", Research in Labor Economics, Vol. 17, pp.151-200.

Cotton, J. (1988). "On the Decomposition of Wage Differentials", The Review of Economics and Statistics, Vol. 70, pp. 236-43.

Gregory, R. G. (1999). "Labour Market Institutions and the Gender Pay Ratio", Australian Economic Review, Vol. 32(3), pp. 273-8.

Gregory, R. G. and Daly, A. (1992). "Who Gets What? Institutions, Human capital and Black Boxes as Determinants of Relative Wages in Australia and the United States", Proceedings of the 9th World Congress, International Industrial Relations Association, Vol. 5, pp. 79-106.

Halvorsen, R. and Palmquist, R. (1980). "The Interpretation of Dummy Variables in Semilogarithmic Equations.” American Economic Review, 70(June), pp. 47475 .

Heckman, J. (1979). "Sample Selection Bias as a Specification Error", Econometrica, Vol. 47, pp. 153-162.

Hundley, G. and Jacobson, C. (1996). "Why Do Women Earn Less than Men in Self-Employment”, Unpublished Paper, University of Western Australia. 
Jones, F.L. (1983). "On Decomposing the Wage Gap: A Critical Comment on Blinder's Method", Journal of Human Resources, Vol. 18, pp.126-130.

Kidd, M. P. (1993a). "Immigrant Wage Differentials and the Role of SelfEmployment in Australia", Australian Economic Papers, Vol. 32(6), pp. 92115 .

Kidd, M. P. (1993b). "Sex Discrimination and Occupational Segregation in the Australian Labour Market", Economic Record, Vol. 69, pp. 44-55.

Kidd, M. P. and Meng, X. (1997). "Trends in the Australian Gender Wage Differential Over the 1980's: Some Evidence of the Effectiveness of Legislative Reform", Australian Economic Review, Vol. 30, pp. 31-44.

Kidd, M. P. and Shannon, M. (1996). "Does the Level of Occupational Aggregation Affect Estimates of the Gender Wage Gap?", Industrial and Labor Relations Review, Vol. 49, No. 2, pp.317-329.

Kidd, M. P. and Viney, R. (1991). "Sex Discrimination and Non-Random Sampling in the Australian Labour Market", Australian Economic Papers, Vol. 30(June), pp. 28-49.

Langford, M. (1995). "The Gender Wage Gap in the 1990's", Australian Economic Papers, Vol. 34(June), pp. 62-85.

Le, A. T. (1998). An Analysis of Self-Employment in the Australian Labour Market, Unpublished Thesis, University of Western Australia.

Le, A. T. and Miller, P. W. (1998) "Pitfalls of Including Current Earnings in Labour Market Choice Estimating Equations", Australian Economic Review, Vol. 34(4), pp. 414-419.

Lee, Y. L and Miller, P. W. (2003). "Screening and Human Capital in the Australian Labour Market of the 1990s", Australian Economic Papers (forthcoming).

Miller, P. W. (1994). "Effects on Earnings of the Removal of Direct Discrimination in Minimum Wage Rates: A Validation of the Blinder Decomposition", Labour Economics, Vol. 1, pp. 347-63.

Miller, P. W. and Rummery, S. (1991). "Male-Female Wage Differentials in Australia: A Reassessment", Australian Economic Papers, Vol. 30, pp. 50-69.

Mincer, J. (1974). Schooling, Experience and Earnings, National Bureau of Economic Research, New York.

Preston, A. C. (1997). "Where Are We Now With Human Capital Theory in Australia?", Economic Record, Vol. 73, pp. 58-78. 
Preston, A. C. (1999). "Female Earnings in 1981 and 1991: A Comparison", Curtin University, School of Economics and Finance, Women's Economic Policy Analysis Unit, Discussion Paper No 1.

Preston, A. C. and Crockett, G. V. (1999). "Equal Pay: Is the Pendulum Swinging Back?”, Journal of Industrial Relations, Vol. 41(4), pp. 561-574.

Puhani, P. A. (2000) "The Heckman Correction for Sample Selection and Its Critique", Journal of Economic Surveys, Vol. 14(1), pp. 53-67.

Reiman, C. (1999). "Has Enterprise Bargaining Affected the Gender Wage Gap in Australia?", Current Research in Industrial Relations, Proceedings of AIRAANZ 99 2, pp. 133-63.

Short, C. (1986). "Equal Pay - What Happened?”, Journal of Industrial Relations, Vol. 28, pp. 315-35.

Stolzenberg, R. M. and Relles, D. A. (1997). "Tools for Intuition About Sample Selection Bias and Its Correction”, American Sociological Review, Vol. 62, pp. 493-507.

Taylor, J. (1993). "The Relative Economic Status of Indigenous Australians, 198691", Research Monograph No. 5, Centre for Aboriginal Economic Policy Research, ANU.

Vella, F. (1993). "Gender Roles, Occupational Choice and the Gender Wage Differential", Economic Record, Vol. 69, pp. 382-92.

White, H. (1980). "A Heteroskedasticity-Consistent Covariance Matrix Estimator and a Direct Test for Heteroskedasticity”, Econometrica, Vol. 48, pp. 817-838.

Whitehouse, G. (1992). "Legislation and Labour Market Gender Inequality: An Analysis of OECD Countries", Work, Employment and Society, Vol. 6(1), pp. 65-86.

Wooden, M. (1999). "Gender Pay Equity and Comparable Worth in Australia: A Reassessment”, Australian Economic Review, Vol. 32, pp. 157-71.

Wooden, M. (2000). The Transformation of Australian Industrial Relations, Australia, Federation Press. 